\title{
Trepanation in the Chachapoya Region of Northern Perú
}

\author{
K. C. NYSTROM* \\ Anthropology and Sociology Department, Santa Clara University, Santa Clara, \\ CA 95053, USA
}

\begin{abstract}
This paper discusses trepanation frequency data from the Chachapoya region of the northern highlands of Perú. New data from three skeletal samples are presented: Kuelap, Laguna Huayabamba, and Los Pinchudos, as well as isolated crania housed at the Chachapoya Museo Instituto Nacional de Cultura. The vast majority of the trepanations are circular in shape, except for one individual exhibiting as many as three roughly square trepanations. Evidence for healing is prevalent, with examples of both associated periosteal reaction of nearby outer table bone, as well as for healing of the insult itself. Only one case demonstrates a clear association between a traumatic injury and a trepanation event. The purpose or function of the remaining cases of trepanation, however, remains elusive. Copyright (c) 2006 John Wiley \& Sons, Ltd.
\end{abstract}

Key words: Chachapoya; trepanation; cranial trauma; ritual

\section{Introduction}

The people referred to ethnohistorically as the Chachapoya occupied a region in northern Perú bounded by the crest of the Central Cordillera of the Andes to the west and the Río Huallaga to the east (Schjellerup, 1997; von Hagen, 2002). Compared with the coast and central highlands of Perú, relatively little archaeological research has been conducted in the region (Bandelier, 1907; Langlois, 1934; Reichlen \& Reichlen, 1950; Schjellerup, 1980/81, 1984, 1997; Kauffmann et al., 1989; Narváez Vargas, 1987; Church, 1994, 1996; Guillén, 1998; Muscutt, 1998; Church \& Morales, 2001; Kauffmann, 2001, 2002; Urton, 2001; Morales et al., 2002; von Hagen, 2002). Based upon the available archaeological evidence, the Chachapoya have been characterised as a confederation of tribes (Schjellerup, 1997)

\footnotetext{
* Correspondence to: Anthropology and Sociology Department, 329 O'Connor Hall, 500 El Camino Real, Santa Clara University, Santa Clara, CA 95053, USA.

e-mail: knystrom@scu.edu
}

sharing broad architectural and symbolic motifs. It appears that the groups may have engaged in regular raiding, leading to a settlement pattern that focused on defensible locations at higher elevations. Immediately preceding Inka intrusion (ca. AD 1472) the Late Chachapoya period (AD 1100-1470) was a time of population growth, along with evidence for increased settlement and monument construction (Schjellerup, 1997). The social and biological changes that may have occurred with the Inka incursion have been examined in depth elsewhere (Nystrom, 2005). There is some evidence for a decrease in regional phenotypic variability during the Late Horizon, but biological distance analyses suggest a close genetic relationship between the Late Chachapoya and Inka period populations. These results are an important consideration when we begin to talk about population-wide frequencies of disease, trauma or, in this case, trepanation. The establishment of the biological relationship between populations is an important first step, grounding all subsequent bioarchaeological research. 


\section{Previous research}

Verano (2003) has produced a synthesis of South American trepanation, tracking geographical and temporal trends over 2000 years. Examples of trepanation can be found in nearly all of the regions of the Peruvian Andes, dating from $400 \mathrm{BC}$ to the Late Horizon (AD 1470-1532). Verano (2003) divided the trepanations into four broad categories: (1) scraping (2) linear cutting $_{i}$ (3) circular grooving; and (4) boring and cutting. The earliest trepanations (400 BC) were produced by the scraping method and appeared on the south coast. The linear cutting technique is most commonly found in the central highlands, although examples of scraping and boring and cutting are known (Verano, 2003: 227). Circular grooving appears in the Late Horizon in the southern highlands.

To date there have been only a few studies that have examined Chachapoya skeletal samples and documented trepanation. Jakobsen et al. (1986/87) and Schjellerup (1997) collected skeletal data $(n=153)$ throughout the course of an archaeological survey of the Chuquibamba Valley, and noted only two crania that were trepanned. In the first, three small holes were drilled into the left frontal bone in a tight circular pattern (Schjellerup, 1997). According to the author, the drill holes did not penetrate the vault. The second example consisted of a semi-circular series of drill holes located on one side of a cranial depression fracture located near bregma. Presumably the segment of damaged cranial bone was removed. Both examples had no evidence of healing. In his examination of 40 Chachapoya skulls obtained from Kuelap, Piedra Grande and Luya, Ruiz Estrada (1994) found that 17\% of the skulls displayed signs of trepanation.

\section{Material and methods}

Three skeletal series were examined for this research, two series from the Late Chachapoya period (AD 1100-1470) and one from the Late Horizon (AD 1470-1532): (1) material from the Revash cultural period from the site of Kuelap $(n=97)_{i}(2)$ the Laguna Huayabamba $(n=25)_{i}$ and (3) the Late Horizon Chachapoya site of Los

Copyright (C) 2006 John Wiley \& Sons, Ltd.
Pinchudos $(n=16)$. Additionally, a number of isolated mummies and crania housed at the Museo de la Instituto de Nacional in the modern city of Chachapoyas were examined.

Sex estimates were based upon traditional cranial morphological features (Buikstra \& Ubelaker, 1994). The development of the supraorbital margin, supra-orbital ridge, mastoid process, nuchal crest, and mental eminence were visually assessed and scored on a scale from 1 to 5, with the former describing a 'female' expression and the latter describing a 'male' expression of a particular trait. In general, there was good separation between the morphological extremes. Four of the five morphological characteristics reliably separated the sexes and followed the established format (Buikstra \& Ubelaker, 1994). Nuchal crest development, however, appeared to be robust for both sexes.

Age estimates were based upon morphological features of the skull and dental eruption patterns. As mentioned above, because of the lack of associated post-cranial remains, age estimation utilising the auricular surfaces or pubic symphyses was impossible.

\section{Kuelap}

The first skeletal sample examined in this research comes from the site of Kuelap (Figure 1), situated in the Province of Luya in the Departmento Amazonas, approximately $35 \mathrm{~km}$ south of the modern departmental capital of Chachapoyas. Initially described in 1843, Kuelap has arguably received the lion's share of archaeological attention of any site in the region, and has generally been described as a fortified city (Wertheman, 1892/93; Bandelier, 1907; Langlois, 1934; Reichlen \& Reichlen, 1950; Horkheimer, 1958; Ruiz Estrada, 1969; Narváez Vargas, 1987). The site covers 450 hectares of a ridge top at 3000 masl and consists of several components. (Narváez Vargas, 1987).

Collected during the course of an archaeological survey of the site by Henry and Paule Reichlen (1950), the occupational history of Kuelap was divided into three phases; Kuelap (AD 1000-1200), Chipurik (AD 1200-1350) and Revash (ca. AD 1350-1470). The skeletal sample

Int. J. Osteoarchaeol. 17: 39-51 (2007) 


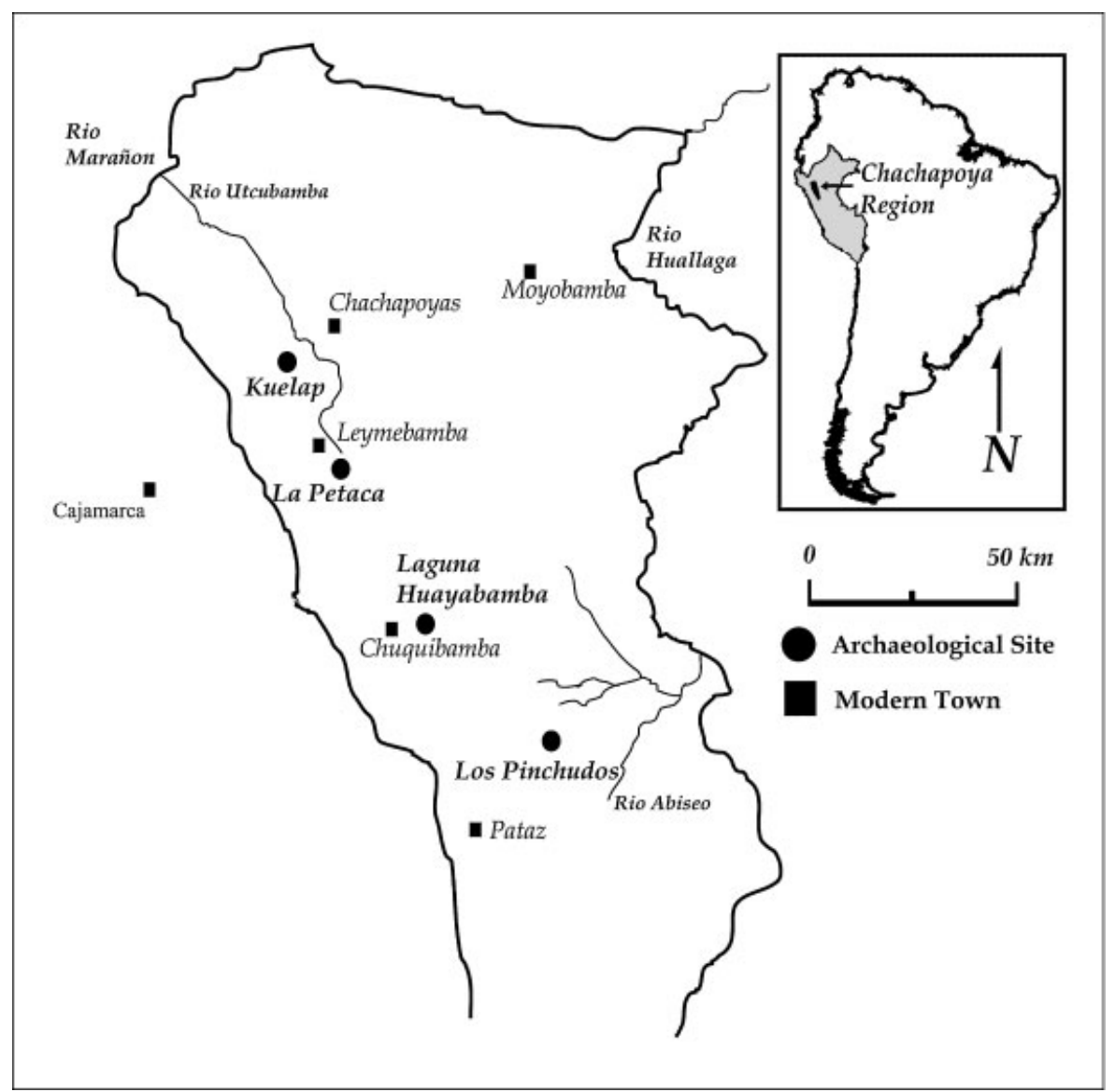

Figure 1. Map of the Chachapoya region, with the archaeological sites discussed in the text highlighted.

was distributed among the three time periods as follows: Kuelap, $n=6$; Chipurik, $n=1$; with the majority of the sample coming from the Late Chachapoya period of Revash, $n=97$. Unfortunately, the archaeological context of the skeletal remains examined in this research is not known. We can only infer that the remains were recovered from within the city itself, based upon context notes written by the Reichlens on the crania themselves. The following analysis and discussion is based upon skeletal material from the last cultural period of Revash (Table 1).

\section{Laguna Huayabamba}

The site of the Laguna Huayabamba is in the Departmento San Martín, on the eastern

Table 1. Age/sex distribution for the Revash portion of the Kuelap collection $(n=97)$

\begin{tabular}{lccccccc}
\hline & $0-12$ & $13-19$ & $20-34$ & $35-50$ & 50+ years & 'Adult' & Total \\
\hline Male & 0 & 0 & 14 & 20 & 7 & 1 & 2 \\
Female & 0 & 0 & 9 & 6 & 10 & 27 \\
Indet. & 14 & 5 & 1 & 3 & 21 & 4 & 28 \\
Total & 14 & 5 & 24 & 29 & & 97 \\
\hline
\end{tabular}


watershed of the Central Cordillera, between the headwaters of the Huayabamba and Totora (Figure 1). The site consists of two components: (1) a residential sector set on the south side of the Laguna Huayabamba, on the summit of a north facing slope; and (2) a funerary component on the north side of the lake. The tomb in which Muscutt and colleagues recovered the human remains was but one of several on the cliff face. Unfortunately, the majority of these other tombs had been extensively looted and disturbed (Muscutt, 2003).

Although the Laguna Huayabamba lies on the purported route of the conquering Inka, there were no indications of an Inka presence at the site (Muscutt et al., 1994). Radiocarbon analysis of textile fibres from one of the mummy bundles yielded a date to approximately AD 1000-1150 (Muscutt, 2003), placing it well before the AD 1472 date of Inka conquest. Supporting ceramic evidence in the form of a Cajamarca floral-cursive bowl substantiates this early date (Muscutt, 2003). The tomb contained mummy bundles, disarticulated skeletal remains, and what appear to be primarily interments.

In general the remains recovered were in excellent condition. There are a total of 48 both skeletal and mummified individuals (Table 2). There were essentially equal numbers of adult males $(n=14)$ and females $(n=13)$ represented. Given the number of individuals that retained significant amounts of soft tissue or were wrapped as mummy bundles, there are a number of adults with indeterminate sex $(n=7)$. There were also a large number of subadult remains recovered $(n=13)$. Because of the amount of soft tissue that remained on a number of the individuals, gross evaluation of trauma was limited to exposed crania (Table 2).

Table 2. Age and sex distribution for the Laguna Huayabamba collection, observable crania only $(n=25)$

0-19 20-34 35-50 $\begin{gathered}50+ \\ \text { years }\end{gathered}$ 'Adult' Total

\begin{tabular}{llllllr}
\hline Male & 0 & 2 & 6 & 2 & 0 & 10 \\
Female & 0 & 2 & 1 & 3 & 0 & 6 \\
Indet. & 8 & 1 & 0 & 0 & 0 & 9 \\
Total & 8 & 5 & 7 & 5 & 0 & 25 \\
\hline
\end{tabular}

Copyright (C) 2006 John Wiley \& Sons, Ltd.

\section{Los Pincbudos}

The site of Los Pinchudos consists of a series of eight cbullpas set within a rock face, near the confluence of the Río Montecristo and Río Abieso (Figure 1). Morales et al. (2002) proposed a four-phase construction series based upon construction and stylistic characteristics, all of which probably took place during a 60-year span during the Late Horizon (Church \& Morales, 2001). Radiocarbon dates derived from wood of chullpa \#1 yielded a calibrated date of $250 \pm 50$ (AD 1657), while straw from a wall of cbullpa \#5 yielded a date of $305 \pm 45$ (AD 1639) (Church \& Morales, 2001; Morales et al., 2002). Ceramic evidence supports a Late Horizon affiliation. Inka style ceramics, both of the Cuzco-derived Imperial Inka ceramics and locally produced Provincial Inka type, were recovered from several of the structures. Inka style white kaolin-rich ceramics were also recovered, probably representing the presence of trade relations with neighbouring highland populations in the Cajamarca region (Church \& Morales, 2001). Morales and colleagues suggested that the interments consisted of members of a single ayllu. In addition, the high quantity and quality of the ceramics recovered suggests that they were a local elite lineage sanctioned by the Inka (Church \& Morales, 2001; Morales et al., 2002).

The skeletal material recovered was disarticulated and the authors conclude that they are the result of a secondary interment ritual (Church \& Morales, 2001; Morales et al., 2002). Bones were associated with nearly all of the structures, including eight interments uncovered on the path that leads into the site. Despite a minimum number of individuals of 186 (Bracamonte, 2002), the available cranial sample size is 16 (Table 3 ).

Table 3. Age and sex distribution of the Los Pinchudos collection $(n=16)$

\begin{tabular}{lcccccc}
\hline & 0-19 & 20-34 & 35-50 & $\begin{array}{c}50+ \\
\text { years }\end{array}$ & 'Adult' & Total \\
\hline Male & 0 & 3 & 4 & 0 & 0 & 7 \\
Female & 0 & 2 & 1 & 2 & 1 & 6 \\
Indet. & 3 & 0 & 0 & 0 & 0 & 3 \\
Total & 3 & 5 & 5 & 2 & 1 & 16 \\
\hline
\end{tabular}

Int. J. Osteoarchaeol. 17: 39-51 (2007) 
Table 4. Age/sex distribution of trepanations for the Revash series (juvenile and adult crania, $n=97$ )

\begin{tabular}{|c|c|c|c|c|c|c|c|c|c|c|c|}
\hline \multirow[t]{2}{*}{ Age } & \multicolumn{2}{|c|}{ Juvenile } & \multicolumn{2}{|c|}{ 20-34 } & \multicolumn{2}{|c|}{$35-50$} & \multicolumn{2}{|c|}{$50+$ years } & \multicolumn{2}{|c|}{ 'Adult' } & \multirow[t]{2}{*}{ Total } \\
\hline & $n$ & N & $n$ & $N$ & $n$ & $N$ & $n$ & $N$ & $n$ & $N$ & \\
\hline Male & 0 & 0 & 3 & 14 & 3 & 21 & 0 & 6 & 0 & 1 & $6 / 42(14 \%)$ \\
\hline Female & 0 & 0 & 1 & 9 & 0 & 8 & 0 & 8 & 0 & 2 & $1 / 27(4 \%)$ \\
\hline Indet. & 1 & 19 & 0 & 1 & 0 & 3 & 0 & 4 & 0 & 1 & $1 / 28(4 \%)$ \\
\hline Total & $1(5 \%)$ & 19 & $4(16 \%)$ & 24 & $3(9 \%)$ & 32 & $0(0 \%)$ & 18 & $0(0 \%)$ & 4 & $8 / 97(8 \%)$ \\
\hline
\end{tabular}

$\mathrm{N}=$ total age/sex sample size.

$n=$ number of trepanations within each age/sex division.

\section{Isolated crania}

In addition to the skeletal series described above, isolated skeletal material housed at the Instituto Nacional de Cultura Museum in Chachapoyas was examined. While there is limited contextual information for this material, it is most likely that the material originated from La Petaca, a cliffside mortuary site near the modern town of Leymebamba, which contains both pre-Inka and Late Horizon components.

\section{Results}

The only skeletal sample with observed evidence of trepanation was the Revash collection from Kuelap. There was no evidence of trepanations for the material from either Los Pinchudos or Laguna Huayabamba.

\section{Kuelap}

The age and sex distribution for the Revash series is presented in Table 1. As is generally expected, the young adult (20-34 years of age) and middle adult (35-50 years) age categories contain the majority of the individuals. What is somewhat unusual is the number of recovered subadult (0-19 years) crania.
With the inclusion of the subadults $(n=19)$, the trepanation rate for the total sample was 9\% (Table 4). There is no significant difference between the age categories $\left(\chi^{2}=3.43, P=\right.$ $0.329)$ or between males and females $\left(\chi^{2}=\right.$ $2.11, P=0.147)$. There was one subadult that displayed evidence of trepanation. The majority of the trepanations occurred on the left frontal bone $(n=5,55 \%)$, followed by the left occipital $(n=2,22 \%)$ (Table 5).

All of the trepanations from the Revash series were round in shape (Figure $2 \mathrm{a}-\mathrm{d}$ ), except for one triangular-shaped defect (Figure 3), although this may be due to the healing process rather than the initial shape of the lesion. There is a slight circular depression surrounding the defect, which may represent the extent of the original lesion, or alternatively an indication of a periosteal reaction due to infection.

The two most noteworthy examples of trepanation come from a juvenile approximately 7 years of age (Revash 2 cráneo \#70) and a young adult male (Revash 2 cráneo \#72). The trepanation in the juvenile is located on the left frontal bone, and measures $35 \times 27 \mathrm{~mm}$ (Figure 4 ). The rim of the trepanation itself is smooth, possibly evidence of long-term healing. Surrounding the trepanation there is a triangular area of periosteal reaction covering an area $60 \mathrm{~mm}$ long and $45 \mathrm{~mm}$ wide at the base.

Table 5. Frequency and occurrence of trepanations by element and side for the Revash series

\begin{tabular}{|c|c|c|c|c|c|c|}
\hline \multicolumn{2}{|c|}{ Frontal } & \multicolumn{2}{|c|}{ Occipital } & \multicolumn{2}{|c|}{ Parietal } & \multirow[t]{2}{*}{ Sagittal suture } \\
\hline Left & Right & Left & Right & Left & Right & \\
\hline $5(55 \%)$ & 0 & $2(22 \%)$ & $1(11 \%)$ & $1(11 \%)$ & 0 & $1(11 \%)$ \\
\hline
\end{tabular}




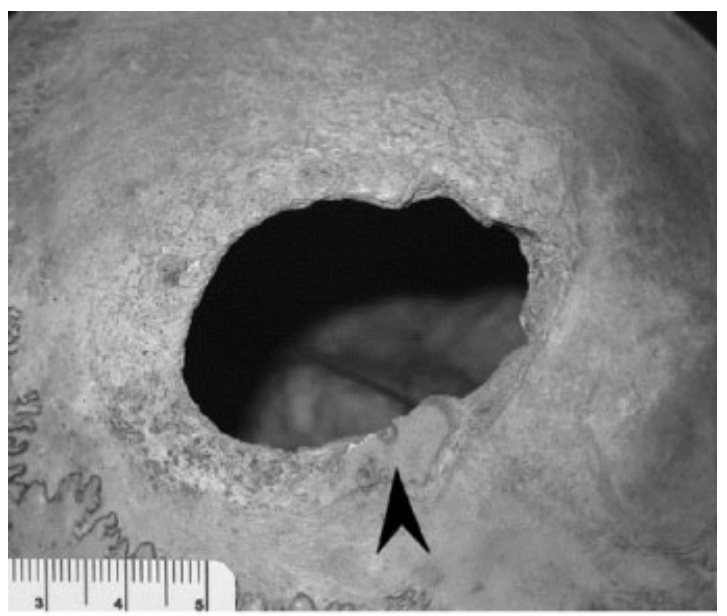

a)

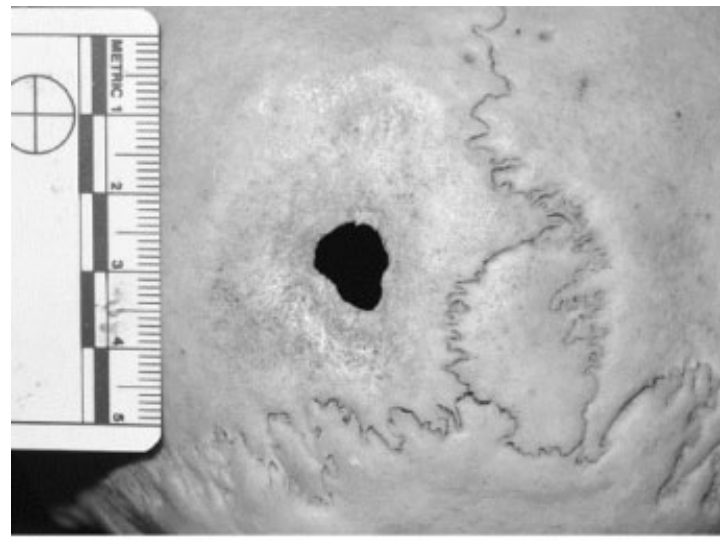

c)

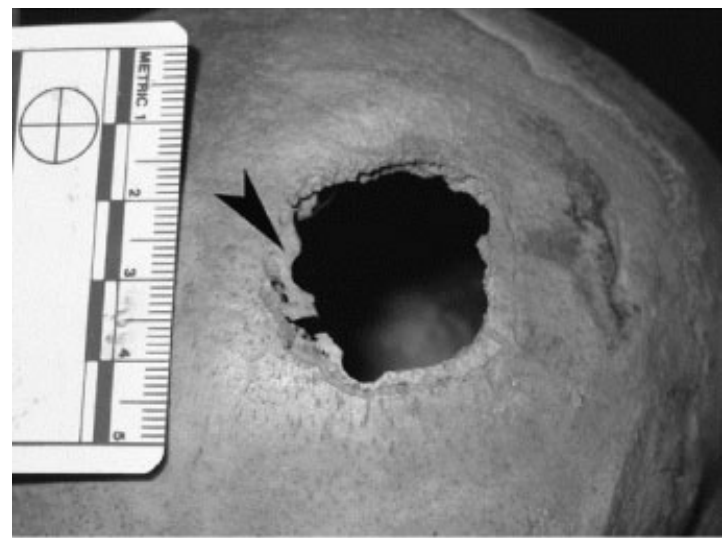

b)

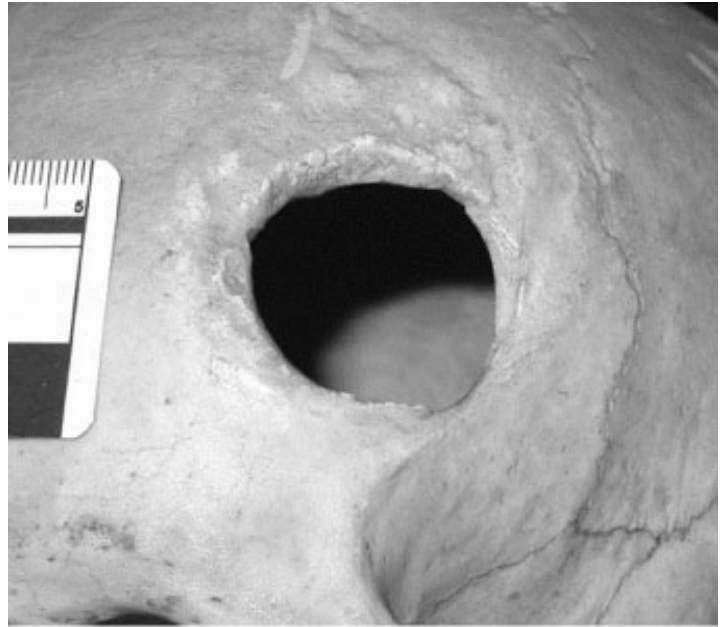

d)

Figure 2. (a) and (b) are examples of trepanations made by circular grooving. The black arrows point to the appositional growth of dense, plaque-like bone. (c) and (d) represent trepanations that demonstrate long-term healing.

The trepanations observed on the young adult male can be separated into two groups (Figure 5). The first is located on the lower left parietal and consists of five distinct drill holes (Figure 5a), while the second is adjacent to the left temporalparietal suture and is a single drill hole (Figure $5 \mathrm{~b}$ ). The drill holes in the first group on the parietal are all externally bevelled and are fairly consistent in their dimensions. The inner dimensions range in diameter from 3 to $5 \mathrm{~mm}$, while the outer dimensions range in diameter from 7 to $10 \mathrm{~mm}$. All of the margins, inner and outer, are sharp and Copyright (C) 2006 John Wiley \& Sons, Ltd. there is no indication of healing or reactive bone. The cortical bone surrounding the area appears plaque-like and dense, similar to the bone marked in Figure $2 \mathrm{a}$ and $2 \mathrm{~b}$. This may represent some sort of appositional bone growth, indicative of prolonged healing (Nerlich et al., 2003: 48). Generally in this type of trepanation procedure the intervening bone is removed, but in this instance it remains. The second lesion is on the border between the temporal and the parietal bones (Figure 5b). This lesion is much more irregular and quite distinct from those described

Int. J. Osteoarchaeol. 17: 39-51 (2007) 


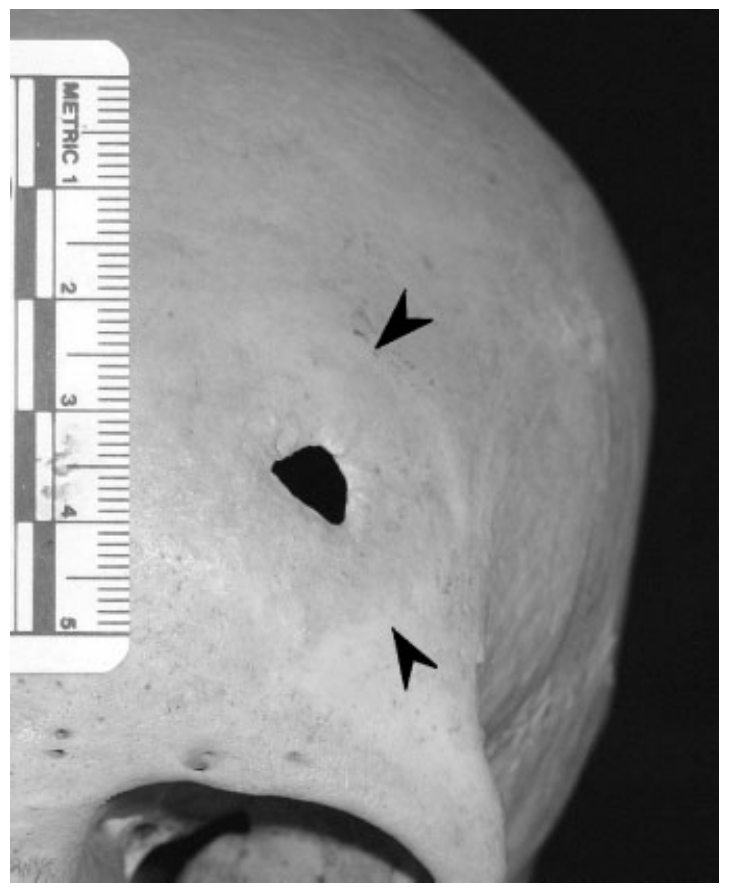

Figure 3. Triangular shaped lesion on left frontal of Revash 2 cráneo \#83. Black arrows mark the edges of a slight circular depression surrounding the lesion. above. The inner diameter measures $10 \mathrm{~mm}$. The outer diameter is less distinct and merges with an area of roughened, reactive bone with an area of approximately $30 \mathrm{~mm}^{2}$. There appears to be an area of reactive bone that extends towards the first group of trepanation holes described above.

\section{Isolated crania}

In addition to the skeletal series discussed above, there are three examples of trepanation from isolated skeletal material housed at the Instituto Nacional de Cultura museum in Chachapoyas that deserve mention. While there is limited contextual information, the material most likely originated from La Petaca, a cliff-side mortuary site near the modern town of Leymebamba which contains both pre-Inka and Late Horizon components. One adult male and two adult females displayed trepanations. Given the small sample size and the likelihood that the sample does not represent a single context, no statistical procedures were performed.

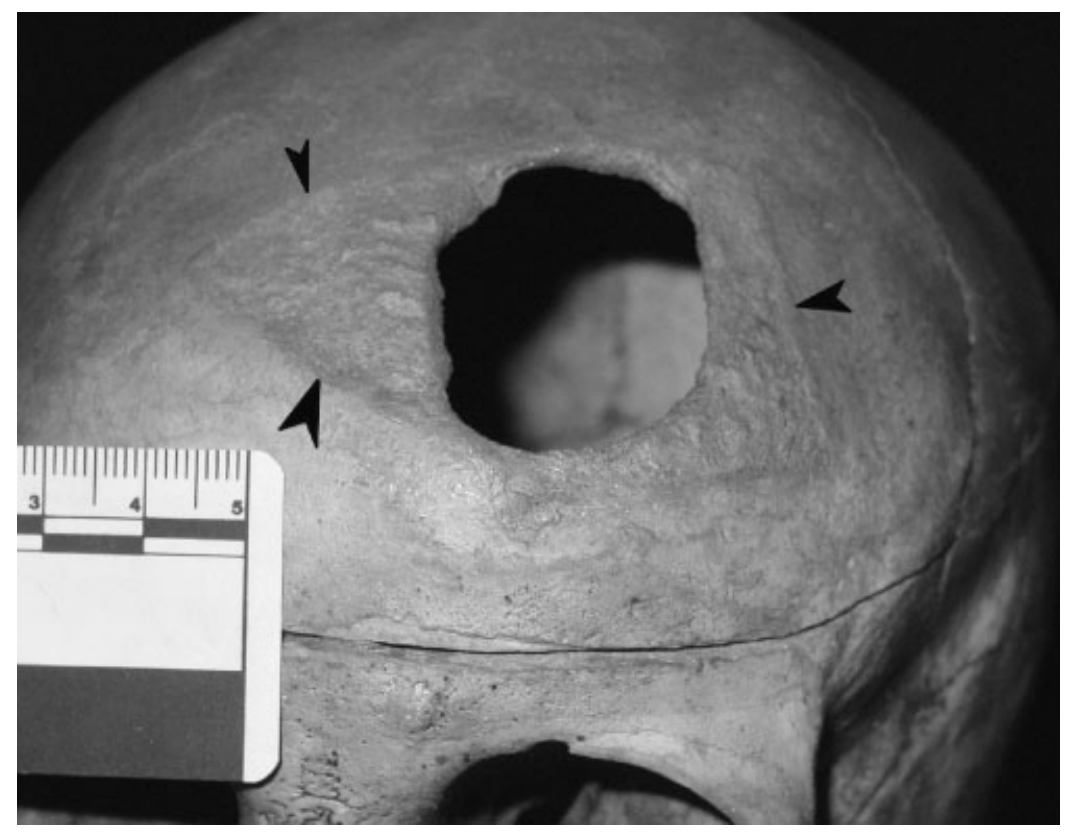

Figure 4. Large circular trepanation on left frontal of Revash 2 cráneo \#70. Black arrows mark the edges of a triangular region of periosteal reaction. 


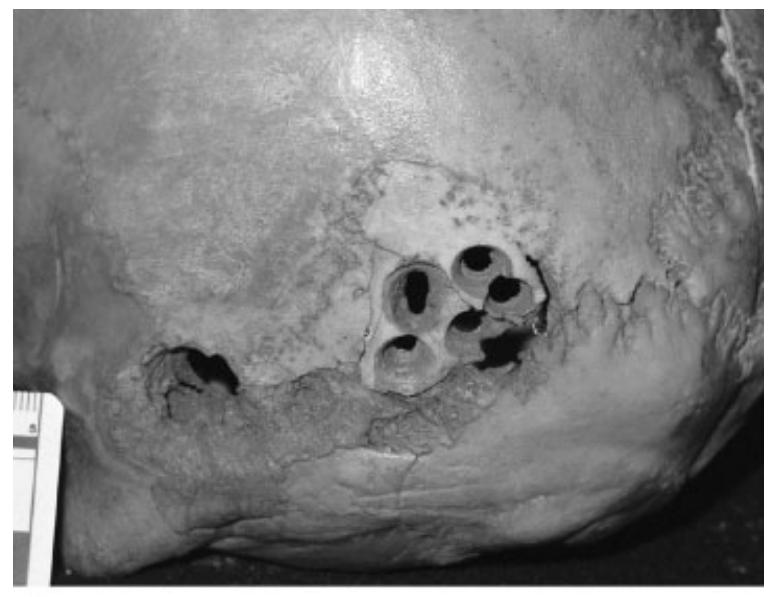

a)

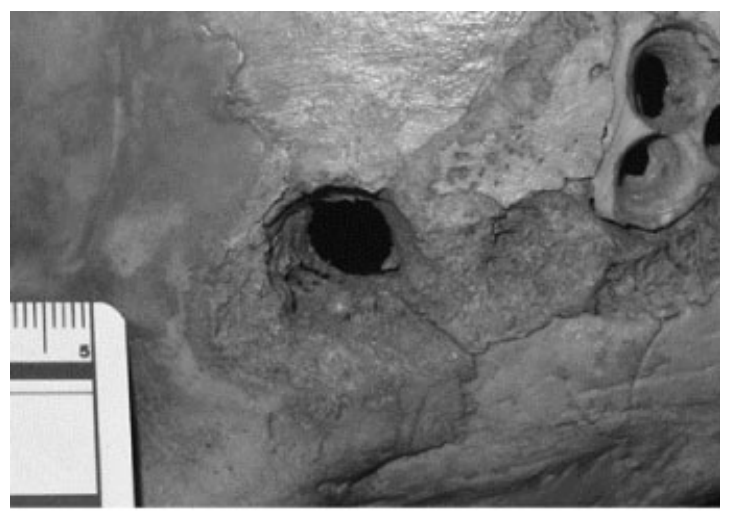

b)

Figure 5. (a) Trepanations on Revash 2 cráneo \#72 made by boring and cutting. (b) Close-up of the second lesion on Revash 2 cráneo \#72.

The lesion on the male is located on the right parietal with extensions that included the left parietal (Figure 6). The lesion consisted of at least nine separate drilling holes with an estimated external diameter of $10 \mathrm{~mm}$ and an internal diameter of $4 \mathrm{~mm}$. The resulting flower pattern measures $36 \mathrm{~mm}$ long by $28 \mathrm{~mm}$ wide. There is no evidence of healing.

The trepanation on the first female cranium is located on the left parietal $22 \mathrm{~mm}$ from the sagittal suture and $26 \mathrm{~mm}$ from the coronal suture (Figure 7). The trepanation consists of four separate drilling holes, creating a roughly rectangular shape which measures $16 \mathrm{~mm}$ wide and $13 \mathrm{~mm}$ long. There appears to be a small 'hesitation' drill Copyright (C) 2006 John Wiley \& Sons, Ltd.

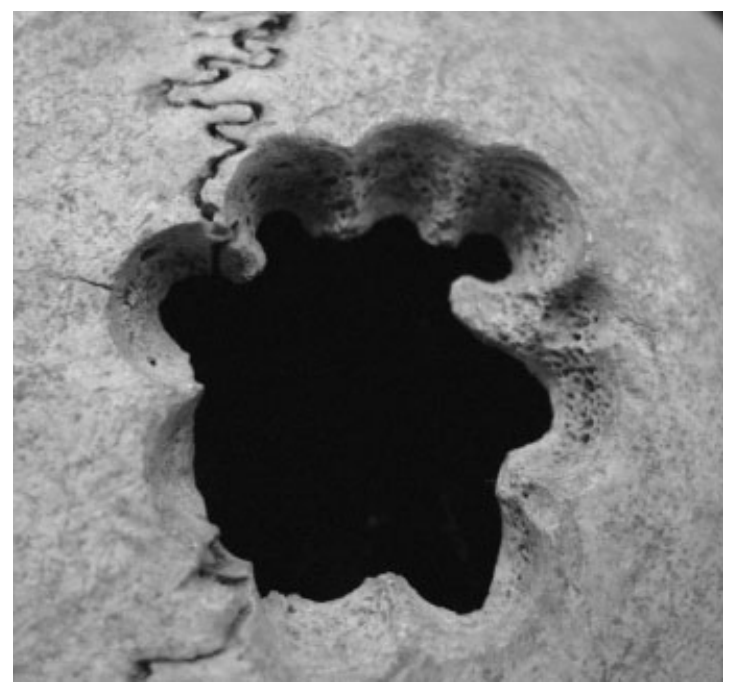

Figure 6. Trepanation made by boring and cutting on the adult male from the INC museum collection in Chachapoyas, Perú.

mark on the anterior side of the trepanation. Furthermore, there are two sets of gouges, one on the anterior edge and the other on the lateral edge. The edges are externally bevelled and there is no evidence of healing.

The second adult female with trepanation was a mummy and has been described in detail by Nystrom et al. (2005). The first trepanation

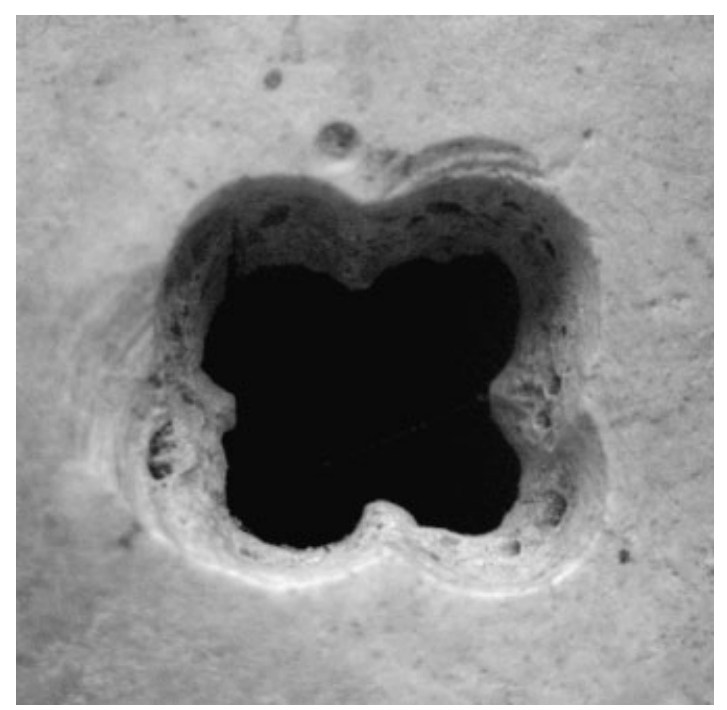

Figure 7. Trepanation on the adult female from the INC museum collection in Chachapoyas, Perú.

Int. J. Osteoarchaeol. 17: 39-51 (2007) 


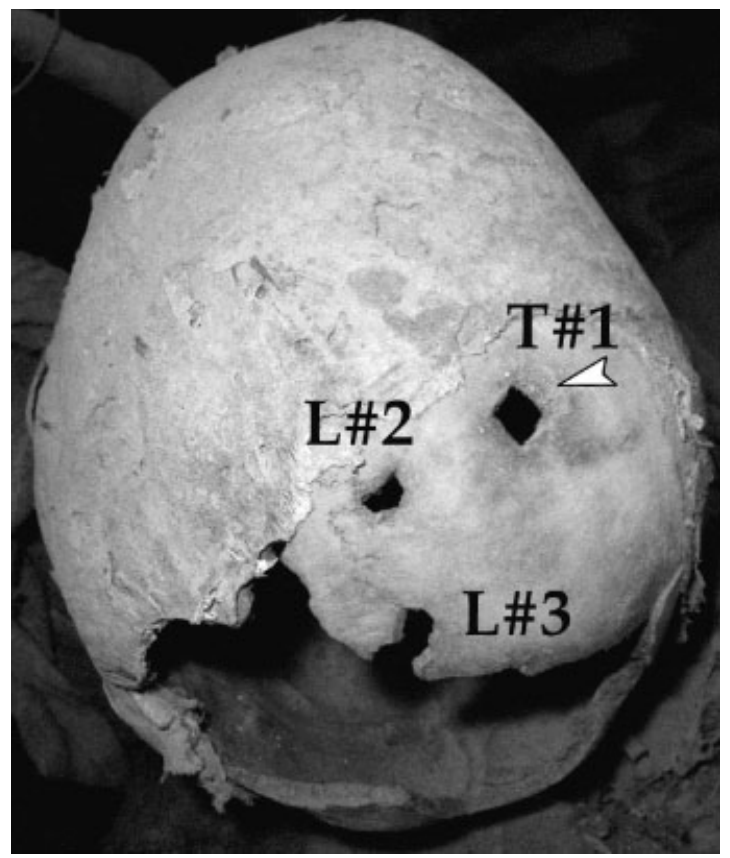

Figure 8. External view of posterior cranium of adult female mummy bundle from the INC museum collection in Chachapoyas. Trepanation \#1 and lesions \#2 and \#3 are marked. The white arrow adjacent to trepanation \#1 points to an area of periosteal reaction.

(designated $\mathrm{T} \# 1$ on Figure 8 ) is approximately $1 \mathrm{~cm}^{2}$ and is located $3 \mathrm{~cm}$ from the sagittal suture on the right parietal. The outer table on the lateral side of the trepanation is roughened and probably represents the presence of reactive bone, possibly a periosteal reaction. The second trepanation (designated $\mathrm{T \# 2}$ on Figure 9) is located on the left parietal just posterior to the coronal suture, is approximately $1 \mathrm{~cm}^{2}$ and is covered externally by a flap of scalp. There are three addition lesions that, while similar in size and shape to the above-reported trepanations, could not be unequivocally defined as such or as fractures (L\#1 and L\#3 on Figure 9, and L\#2 on Figure 8).

\section{Discussion}

Skeletal research in the Chachapoya region has been limited. Reichlen \& Reichlen (1950) collected crania from the site of Kuelap, but they did not publish any conclusions. Pia (1988) also studied crania from Kuelap, recovered during the excavation of several residential structures. Her conclusions dealt primarily with describing morphology and contrasting Inka versus Chachapoya skulls. Schjellerup (1997) and Jakobsen et al. (1986/87) collected significant amounts of skeletal data throughout the course of their research in the Chuquibamba region. They noted that out of 153 skulls, there was a $23 \%$ craniofacial fracture rate and only two examples of trepanation. Both examples came from males and consisted of small drill holes with no evidence of healing. In his
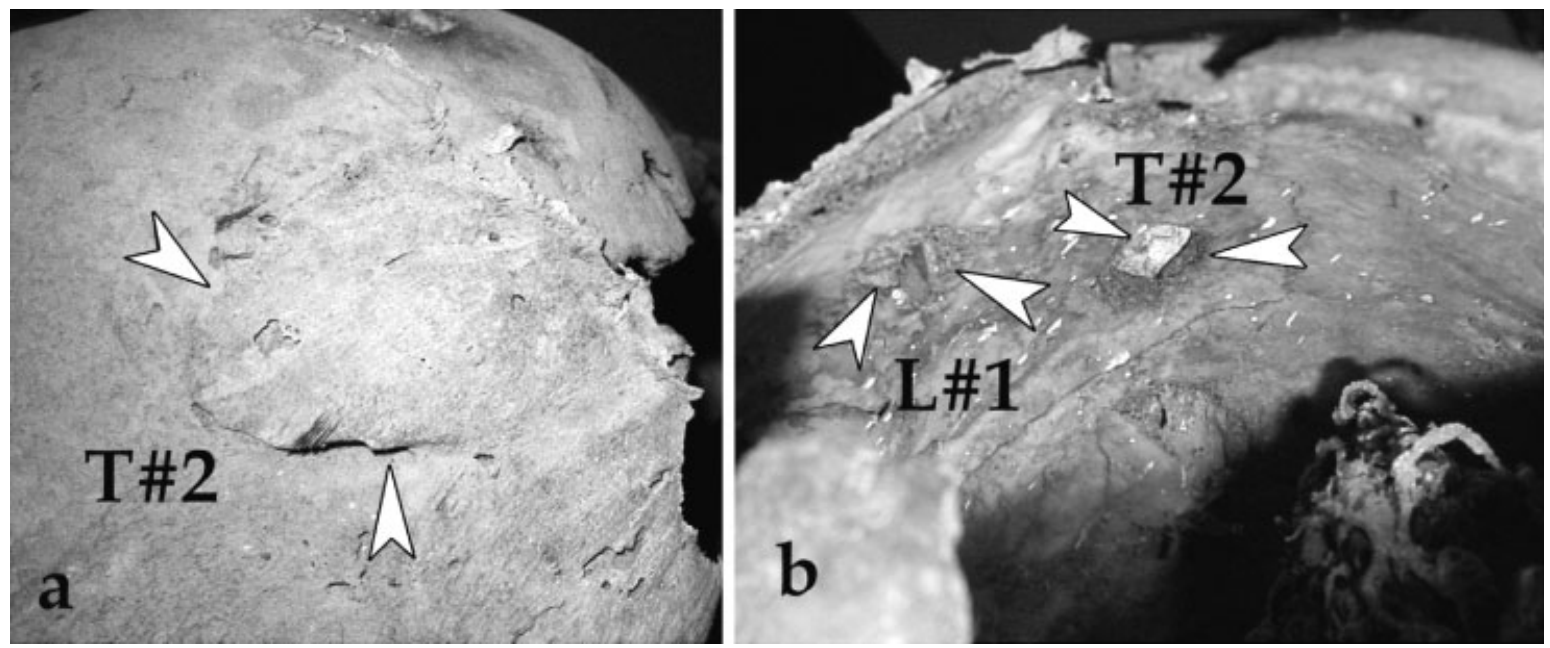

Figure 9. (a) External view of skin flap that covers trepanation \#2 (arrows point to edge of skin flap). (b) Internal view of trepanation \#2. The spatial relationship to L\#1 is also indicated. 
examination of 40 Chachapoya skulls obtained from Kuelap, Piedra Grande and Luya, Ruiz Estrada (1994) found that $17 \%$ of the skulls displayed signs of trepanation. All of these trepanations were circular drill holes.

\section{Kuelap}

It is interesting that no trepanations were evident in the Laguna Huayabamba and the Los Pinchudos series. It is not possible to attribute this to cultural or temporal differences between the samples. It is more likely caused by the vagaries of the archaeological record and collection. The only skeletal sample in which trepanation was observed was from the Revash cultural period of Kuelap (Table 6). Out of 97 crania, 8\% displayed trepanations. All of the trepanations were circular (Table 6) and manifested as (1) single holes or (2) clusters of drill holes with the subsequent removal of the intervening bone. The trepanation technique of the former was most probably circular grooving (Figure 3), while the latter was boring and cutting (Figure 4). In the latter, the number of drill holes ranged from four to as many as nine. As indicated in the Results section above, there was no significant difference between age groups and between sexes. This result, however, must be tempered by the consideration of the small sample size of trepanned individuals $(n=8)$. Based solely on percentages, the males were more commonly affected, similar to that observed by Verano (2003). Also similar to Verano's (2003) research, the majority of trepanations observed were on the left side of the cranium (Table 5). While it has been suggested that this reflects the treatment of cranial trauma received from right-handed opponents, there was no evidence of cranial trauma in the trepanned individuals, although this does not negate the possibility of non-observable soft tissue trauma (Verano, 2003).

Verano (2003: 231) noted that healing rates increased from the earliest south coast trepanations to the later central highland trepanations. Additionally, higher healing rates were associated with the scraping and circular grooving techniques. In the current research, the majority (91\%) of the trepanations demonstrated evidence of healing (Table 6). Evidence of healing ranged from a periosteal reaction probably associated with a soft tissue infection of the scalp (Figure 3) to evidence of an osteoblastic reaction that was directly associated with the trepanation defect (Figure $2 \mathrm{a}-\mathrm{d}$ ). There also seems to be some relationship between technique and probability of survival. Most of those trepanations produced

Table 6. Summary of age, sex, location, shape, and evidence of healing for the series discussed in this research

\begin{tabular}{|c|c|c|c|c|}
\hline $\operatorname{Age}^{1} / \operatorname{sex}^{2}$ & Location & Technique $^{3}$ & Evidence of healing 4 & Figure \\
\hline \multicolumn{5}{|l|}{ Revash } \\
\hline YA/M & Right occipital & CG & $Y / L$ & Figure 2a \\
\hline YA/M & Left frontal & CG & $Y / L$ & Figure $2 \mathrm{~b}$ \\
\hline YA/F? & Left occipital & $?$ & $Y / L$ & Figure 2c \\
\hline $\mathrm{MA} / \mathrm{M}$ & Left frontal & $\mathrm{CG}$ & $Y / L$ & Figure 2d \\
\hline $\mathrm{MA} / \mathrm{M} ?$ & Left frontal & CG? & $Y / L$ & Figure 3 \\
\hline Juve/? & Left frontal & $\mathrm{CG}$ & $Y / L$ & Figure 4 \\
\hline \multirow[t]{2}{*}{ YA/M? } & Left occipital & $B \& C$ & $\mathrm{~N}$ & Figure $5 a$ \\
\hline & Left occipital & $B \& C$ & N & Figure $5 b$ \\
\hline \multirow{2}{*}{ YA/M } & Left parietal & $?$ & $Y / ?$ & \\
\hline & Left frontal & $?$ & $Y / ?$ & \\
\hline \multicolumn{5}{|c|}{ Isolated crania } \\
\hline $\mathrm{A} / \mathrm{M}$ & Right parietal & Round & $\mathrm{N}$ & Figure 6 \\
\hline $\mathrm{A} / \mathrm{F}$ & Left parietal & Round & N & Figure 7 \\
\hline \multirow[t]{2}{*}{$\mathrm{A} / \mathrm{F}$} & Right parietal & Rectangular & $Y / S$ & Figures 8,9 \\
\hline & Left parietal & Rectangular & $\mathrm{N}$ & Figures 8, 9 \\
\hline
\end{tabular}

1Juve = juvenile; $Y A=$ young adult; $M A=$ middle adult; $O A=$ old adult; $A=$ adult.

${ }^{2} \mathrm{M}=$ male; $\mathrm{M}$ ? = probable male; ?= indeterminant; $\mathrm{F}$ ? = probable female; $\mathrm{F}=$ female.

${ }^{3} \mathrm{CG}=$ circular grooving; $\mathrm{B} \& \mathrm{C}=$ boring and cutting.

${ }^{4} \mathrm{~L}=$ evidence of long-term healing; $\mathrm{S}=$ evidence of short-term healing. 
by the circular groove method displayed evidence of long-term healing. On the other hand, the individual with the boring and cutting trepanation (Figure 5) does not show evidence of healing.

\section{Isolated crania}

The trepanations observed on the isolated crania at the INC museum in Chachapoyas were produced by the boring and cutting technique (Figures 6 and 7). There was no evidence of shortor long-term healing. When contrasted with the healing rate associated with the circular grooving trepanations from Kuelap, it seems that this latter technique produced 'better' results for the patient. The mummy housed at the same museum is the only individual with rectilinear trepanations (Figures 8 and 9). It is possible that these lesions were produced by some form of blunt force trauma. Housed at the museum were stone maces that were similar in size and shape to the lesion. This possibility was ultimately rejected, however, given that both tables of the cranium were affected, and there were no associated linear fractures. If these lesions are indeed trepanations, then they are unusual in that they do not have thelinear extensions at the corners that are commonly found associated with this type.

Trying to determine the why of trepanation is a common question. In general, trepanations have been viewed as some form of surgical intervention (Zimmerman et al., 1981; Martin, 2003) or as having some ritual or thaumaturgic purpose (Lisowski, 1967; Aufderheide \& RodríguezMartin, 1998). Of the specimens examined for this research, only the mummy bundle held at the INC museum in Chachapoya demonstrates a clear association between cranial trauma and trepanation. Additionally, the two instances of trepanation described by Schjellerup (1997) are associated with cranial trauma. On the other hand, it is not possible to associate any of the trepanations from Kuelap with cranial trauma. Can we therefore conclude that Chachapoya trepanation tradition had more of a ritual, rather than a medical, function? Bandelier (1907) recounted tales of powerful wizards living in the vicinity of Kuelap, and ethnohistorically the

Copyright (C) 2006 John Wiley \& Sons, Ltd
Chachapoya have been characterised as powerful witch-doctors and medicine men (Schjellerup, 1997). Perhaps this presumed medical knowledge explains the large number of individuals that survived the trepanation, but again, given the paucity of contextual data, this conclusion must remain speculative. Some contextual information, presumably written by the Reichlens themselves, suggests that the skulls were recovered from house or wall contexts, although exactly where is not known. Did the skulls play a role in ancestor veneration? It is possible that all of the remains represent some special class of burial, being entombed in the walls of the site. Burial in the walls may have been granted a special significance, and it has been suggested that the walls of Kuelap are culturally constructed analogues of the cliff faces which are common sites of Chachapoya interments (Bradley, 2005). Indeed, Pia (1988) concluded that the house burials in Kuelap were the remains of sacrificial victims and therefore may have been granted a place in this sacred landscape.

The results presented here broadly fit the pattern established by Verano (2003). There is evidence for two different trepanation methods from the Chachapoya region of northern Perú: circular grooving, and boring and cutting. There was no significant association between sex or age and trepanation, but males were more commonly affected. Given that the Spanish Chroniclers remark on the bellicose nature of the Chachapoya and their skills in war, it is interesting that trepanations were clearly associated with cranial trauma in only one individual, a female mummy of unknown context and provenance. Craniofacial trauma rates, often taken as a proxy of warfare, reached $16 \%$ for the Revash period of Kuelap (Nystrom \& Verano, 2003). Other samples produced slightly higher rates: $20 \%$ from Los Pinchudos (Bracamonte, 2002); 21\% from Chiquibamba Valley samples (Jakobsen et al., 1986/ 87; Schjellerup, 1997); and 11\% from the Laguna Huayabamba (Nystrom, 2004). As discussed above, however, there were no trepanations observed on the Los Pinchudos material, and Schjellerup (1997) and Jakobsen et al. (1986/87) only documented two instances of trepanation. Finally, it is interesting to note that the Chachapoya have also been described as skilled 
doctors and powerful shamans, and that the majority of individuals discussed above survived trepanation. Even the powerful Inka emperor Huayna Capac called upon the services of a Chachapoya doctor called Chuquimis. Unfortunately, Chuquimis was blamed for Huayna Capac's death (Schjellerup, 1997) and his malpractice resulted in his bones being unceremoniously buried in the ground.

\section{Acknowledgements}

Funding for this research was provided by the National Science Foundation Doctoral Improvement Grant \#0242941, Latin American and Iberian Institute of UNM, and the Graduate Students and Professional Association of UNM. I would like to thank Keith Muscutt and Jesus Briceño for their assistance in gaining access to the Laguna Huayabamba material. Access to the Los Pinchudos material was graciously granted by Warren Church and Ricardo Morales, while Melana Cáceres Esquivel provided access to the Museo INC material. I would also like to thank Claudia Grimaldo and Rob Dover for their invaluable assistance. Finally, the comments of Shelley Saunders and three anonymous reviewers improved the manuscript.

\section{References}

Aufderheide AC, Rodríguez-Martín C. 1998. The Cambridge Encyclopedia of Human Paleopathology. Cambridge University Press: Cambridge.

Bandelier A. 1907. The Indians and Aboriginal Ruins Near Chachapoyas in Northern Peru. Historical Records and Studies.

Bracamonte Ganoza F. 2002. Los Pinchudos: un estudio preliminary de su población. Sian 8(12): $14-15$.

Bradley R. 2005. The Architecture of Kuelap. PhD dissertation, Columbia University, New York City, New York.

Briceno JR, Muscutt K. 2004. Fardos funerarios Chachapoya en la Laguna Huayabamba. Proceedings of the Primera Conferencia Internacional sobre el Arte, la Arqueología y la Etnohistoria de los Chachapoya, Leymebamba, Perú. Sian año 9, no. 15: 6-7.
Buikstra JE, Ubelaker E (eds). 1994. Standards for Data Collection from Human Skeletal Remains. Proceedings of a Seminar at the Field Museum of Natural History. Fayetteville, AR. Arkansas Archaeological Survey, Research Series No. 44.

Church WB. 1994. Early Occupations at Gran Pajatén, Peru. Andean Past 4: 281-318.

Church WB. 1996. Prehistoric Cultural Development and Interregional Interaction in the Tropical Montane Forests of Perú. PhD dissertation, Yale University.

Church WB, Morales Gamarra R. 2001. Emergency Archaeology at the Tombs of Los Pinchudos, Perú. Report to the National Geographic Society Committee for Exploration and Research. Report in possession of the author.

Guillén SE. 1998. Laguna de los Condores: donde Viven los Muertos. Bien Venida 6(24): 43-48.

Horkheimer H. 1958. Algunas consideraciones acerca dela Arqueología en el Valle del Utcubamba. Actas y trabajos del II Congreso Nacional de Historía del Perú. Epoca Pre-Hispánica, Vol. I. Lima; 71-90.

Jakobsen J, Jorgensen JB, Jorgensen LK, Schjellerup I. 1986/87. "Cazadores de Cabezas" En Sitios Pre-Inca de Chachapoyas, Amazonas. Revista del Museo Nacional 48: 139-185.

Kauffmann DF. 2001. Los Sarcófagos de Carajía. Arkinka 65: 76-90.

Kauffmann DF. 2002. Historia y Arte del Perú Antiguo, Vol. 4, PIESA: Lima, Perú.

Kauffmann DF, Salazar M, Morales D, Mackay I, Sacay O. 1989. Andes Amazonicos: Sitios intervenidos por la Expedición Antisuyo/86. Arqueologicas 20. Museo Nacional de Antropología y Arqueología: Lima, Perú.

Langlois L. 1934. Las Ruinas de Cuelap. Boletin de la Sociedad Geograpbica de Lima 51: 20-34.

Lisowski FP. 1967. Prehistoric and early historic trepanation. In Diseases in Antiquity, Brothwell D, Sandison AT (eds). Charles C. Thomas: Springfield, IL; 651-672.

Martin G. 2003. Why trepan? Contributions from medical history and the South Pacific. In Trepanation: History, Discovery, Theory, Arnott R, Finger S, Smith CUM (eds). Swets and Zietlinger Publishers: Lisse; 323-345.

Morales GR, Alvarez LV, Church WB, Tello LC. 2002. Los Pinchudos: un estudio preliminar de su población. Sian 8(12): 1-41.

Muscutt K. 1998. Warriors of the Clouds: A Lost Civilization in the Upper Amazon of Perú. University of New Mexico Press: Albuquerque.

Muscutt K, Lee VR, Sharon D. 1994. Vira Vira: a "new" Chachapoyas site. South American Explorer 39: 5-30. 
Narváez Vargas AL. 1987. Kuelap: una ciudad forticada en los Andes nor-orientales de Amazonas, Peru. In Arquitectura y Arquología: Pasado y futuro de la construccíon en el Perú, Flores VR (ed.). Universidad de Chiclayo: Perú, $115-142$.

Nerlich A, Peschel O, Zink A, Rösing FW. 2003. The pathology of trepanation: differential diagnosis, healing and dry bone appearance in modern cases. In Trepanation: History, Discovery, Theory, Arnott R, Finger S, Smith CUM (eds). Swets and Zietlinger Publishers: Lisse ${ }_{4}$ 43-51.

Nystrom KC. 2004. Trauma y identidad entre los Chachapoya. Proceedings of the Primera Conferencia Internacional sobre el Arte, la Arqueología y la Etnohistoria de los Chachapoya, Leymebamba, Perú. Sian 9(15): 20-21.

Nystrom KC. 2005. The Biological and Social Consequences of the Inka Conquest of the Chachapoya of Northern Perú. $\mathrm{PhD}$ dissertation, University of New Mexico, Albuquerque.

Nystrom KC, Goff A, Goff ML. 2005. Mortuary behaviour reconstruction through palaeoentomology: a case study from Chachapoya, Perú. International Journal of Osteoarchaeology 15: 1-11.

Nystrom KC, Verano JW. 2003. Warriors of the Clouds? Inferences and Interpretations of Trauma from Chachapoyas, Perú. Presented at the 72nd Annual Meeting of the American Association of Physical Anthropologists, Tempe, AZ, April 23-26, 2003.

Pia GE. 1988. Osteological report from excavations at Kuelap. Instituto Nacional Cultura, Amazonas. Report in possession of the author.

Reichlen H, Reichlen P. 1950. Recherches Archéologiques dans les Andes de du Huat Utcubamba. Journal de la Société des Américanistes 34: 219-251.

Ruiz Estrada A. 1969. Alfareria del Estilo Huari en Cuelap. Boletin del Seminario de Arqueologia 4: 60-65.
Ruiz Estrada A. 1994. La Cirugia Prehispanica en el Departmento de Amazonas, Perú. Sequilao 3(7).

Schjellerup I. 1980/81. Documents on stone and in paper. A preliminary report on Cochabamba, an Inca administrative center. Folk 22/23: 299311.

Schjellerup I. 1984. Cochabamba-an Inca administrative centre in the rebellious province of Chachapoyas. International Congress of Americanists, Manchester 1982. BAR International Series 210: 161187.

Schjellerup I. 1997. Incas and Spaniards in the Conduest of the Chachapoyas, Archaeological and Ethnobistorical Research in the North-eastern Andes of Peru. GOTARC series B, Gothenburg Archaeological Theses, 7. Göteborg University.

Urton G. 2001. A calendrical and demographic tomb text from northern Perú. Latin American Antiquity 12 : 127-148.

Verano JW. 2003. Trepanation in prehistoric South America: geographic and temporal trends over 2,000 years. In Trepanation: History, Discovery, Theory, Arnott R, Finger S, Smith CUM (eds). Swets and Zietlinger Publishers: Lisse; 223-236.

von Hagen A. 2002. Chachapoya Iconography and Society at Laguna de los Cóndores, Perú. In Andean Archaeology Volume II: Art, Landscape, and Society, Silverman H, Isbell WH (eds). Kluwer Academic/ Plenum Publishers: New York; 137-155.

Wertheman A. 1892-93. Ruinas de la fortaleza de Cuelap. Boletin de la Sociedad Geographica de Lima 2: 147-160.

Zimmerman MR, Trinkaus E, Lemay M, Aufderheide AC, Reyman TA, Marrocco GR, Shultes RE, Coughlin EA. 1981. Trauma and trephination in a Peruvian mummy. American Journal of Physical Antbropology 55: 497-501. 